\title{
THE SWEDISH FREE MISSION (SFM) WORK IN KENYA BETWEEN 1960 AND 1984
}

\author{
Stephen Muoki Joshua \\ Pwani University \\ University of South Africa \\ pastastevo@yahoo.co.uk
}

\section{Edward Mungai}

Free Pentecostal Fellowship in Kenya (FPFK)

edward.mungai@yahoo.com

\section{David Musumba}

Free Pentecostal Fellowship in Kenya (FPFK)

dmusumba@gmail.com

\section{ABSTRACT}

This article is a descriptive account of early missionary work of the Swedish Free Mission (SFM) in Kenya during the last part of the colonial era after national independence in 1964. It attempts to reconstruct a memory of surviving local clerics and missionaries on their collaborative work in birthing a local church, the Free Pentecostal Fellowship in Kenya (FPFK). It relies on 20 in-depth interviews conducted by the authors in 2014, as well as missionary records found in FPFK's head office in Nairobi.

Keywords: Swedish Free Mission (SFM); Kenya; missionary work; colonial era; 1964 independence; Free Pentecostal Fellowship in Kenya (FPFK)

\section{UNISA}




\section{INTRODUCTION}

The Free Pentecostal Fellowship in Kenya (FPFK) is a local church registered in Kenya since 1977. The church has over 170000 members and about 500 local church congregations which are organised into 28 regions spread across the country. ${ }^{1}$ The FPFK owes its origin to Scandinavian missionary work in East Africa. Two missionary societies in Kenya, the Swedish Free Mission (SFM) which later changed its name to the Evangelical Free Mission, and the Norwegian Pentecostal Mission, consolidated their work in Kenya to register the FPFK. The Norwegian Pentecostal Mission contributed the term 'pentecostal' whereas the SFM contributed the term 'free' to form the Free Pentecostal Fellowship in Kenya. ${ }^{2}$ The two missionary agencies were already in Kenya in the late 1950s, not long before the country became independent in 1964.

Arguably, the earliest talks on a merger between these missionary bodies were during a joint meeting held in 1976 at Lumumba Hall in Roysambu, Nairobi. This comprised five organisations: Maranatha, Full Gospel, East African Pentecost, Evangelical Free Mission (EFM), and Norwegian Pentecostal Mission (NPM). Their key purpose of meeting was to collaborate and unite in the field of mission. The objectives were: (1) to avoid overlapping in evangelistic works; and (2) to avoid duplication of project work in specific regions and funding sources. ${ }^{3}$ At the proceedings of that meeting, a merger was found to be necessary; an idea fully supported by the EFM and NPM. However, others declined due to various reasons. The Full Gospel, which was from Finland, did not want to collaborate with these others due to its long history of missionary presence in Kenya. The Full Gospel felt that they had been in Kenya for far too long and were more established. The East African Pentecostals were also not interested in the merger. ${ }^{4}$

The EFM and NPM discussed what the name of the merger organisation should be. They unanimously agreed on 'Free Pentecostal Fellowship in Kenya (FPFK)'. In 1977, after the merger meeting in Lumumba, they went ahead and registered the new FPFK with the registrar of societies in Kenya. However, it was not until 1984 when the two bodies worked together under FPFK registration. ${ }^{5} \mathrm{~A}$ letter by Maud Anderson, the General Secretary of FPFK on 26 May 1984 advised that: 'Properties held in the name of EFM will be held in trust by the registered trustees of the EFM pending the conclusion of all formalities after which they will be transferred and

$1 \quad$ FPFK assessment report by Taabco, dated 2013, page 14-19.

2 Letter by Maud Anderson, General Secretary of Evangelical Free Mission in Kenya, to the Registrar of Societies, Nairobi, titled Notification of Dissolution on 26 May 1984.

3 Maud Anderson, interview by Stephen Muoki Joshua at FPFK headquarters on 7 December 2014.

4 Maud Anderson, interview by Stephen Muoki Joshua at FPFK headquarters on 7 December 2014.

5 Minutes Number 20 taken at the first Joint AGM of the FPFK at Karen Bible School on 26 May 1984. 
vested in the name of the registered trustees of the Free Pentecostal Fellowship of Kenya. ${ }^{6}$

This article is an attempt to reconstruct the history of the SFM in Kenya from 1960 when it started to work in Kenya, up until 1984 when it merged with its Norwegian counterpart. It relies on oral interviews, missionary reports and archival material.

\section{Early missionary activities of the Swedish Free Mission in Kenya}

According to a letter written by Maud Anderson, General Secretary of the Evangelical Free Mission in Kenya (EFM) on 14 July 1995, in 1958 the Pentecostal churches of Sweden decided to send out missionaries to Kenya to come and establish churches. As a result, Rev. Gustav Struble was sent from Sweden and arrived in Kenya in 1960. Rev. Gustav and Maria Struble were born in Sweden in 1884 and 1893 respectively. They were sent by the Filadelfia church in Stockholm to establish work in Nakuru. Upon their arrival in Kenya, they settled in Menengai, Nakuru. Rev. Gustav Struble was employed as a farm manager by a British settler called Joe, who in 1962 gave him 20 acres to build a church. ${ }^{7}$ This is part of the location where the Menengai church is situated ${ }^{8}$ which was inaugurated in $1963 .{ }^{9}$ He would pick up people from the farm villages and bring them to church and back after Sunday services on his pick-up van. Munyasya and his wife Eda, who became the first African evangelists, were working with the missionary in those early days. They began a nursery school which later became Menengai Primary School. In addition, Rev. Struble started a Bible School on the compound of the church, where many of the present FPFK pastors had their initial ministerial training. African Evangelists who had been trained in Menengai were sent out to different places such as North Kinangop, Nyeri and Kakamega, where they established churches.

When Rev. Struble received his $70^{\text {th }}$ birthday present in the form of funds he used it for the construction of Kinangop church at the foot of Mt Kenya. ${ }^{10}$ After increased evangelical work and the establishment of various congregations, a

6 Letter by Maud Anderson, General Secretary of FPFK, to the Registrar of Societies, Nairobi, titled Notification of Dissolution on 26 May 1984.

7 Anania Mwangi, interview by Rev. Edward Mungai, digital recording at FPFK headquarters on 29 October 2014.

8 Mwangi, interview by Rev. Edward Mungai, digital recording at FPFK headquarters on 29 October 2014.

9 Willy Munene, interview by Rev. Edward Mungai, digital recording at FPFK headquarters on 29 October 2014.

10 Maud Anderson, interview by Stephen Muoki, digital recording at FPFK headquarters on 7 December 2014. 
registration was necessary. ${ }^{11}$ The church was then registered as the Swedish Free Mission (SFM) on 23 February 1963 by the registrar of societies within the Kenya Colony (Protectorate). ${ }^{12}$ The name Swedish Free Mission (SFM) was used until 14 October 1971 when it changed to Evangelical Free Mission (EFM) in Kenya. ${ }^{13}$

Other missionaries who arrived in the early days of the Swedish mission work in Kenya were Miss Eva Danielsson, who arrived in Nakuru in 1965, as well as Einar Karlsson, who went to Nyeri the same year. In the same year, Ulla Struble, daughter of Struble, and Rhode, the son of Struble, joined their parents in Nakuru Missionary work. They established work in and around Nairobi in places such as Kawangware, Kangemi, Gikambura and Eastleigh. ${ }^{14}$ In 1969 an agreement was made to publish an East African Pentecostal magazine named Habari Maalum. The magazine stopped being distributed in Kenya in the late 1980s but continued in Tanzania.

\section{RENEWED MISSIONARY INTEREST IN THE 1970 S}

From the year 1970, there was a considerable increase in the interest abroad for Swedish missionaries to visit Kenya on account of encouraging missionary reports. Notably, Swedish missionaries in Tanzania were finding Kenya the better alternative to the changing land policy under the Ujamaa socialist ideal. A major shift in leadership came in 1974 when Struble was suddenly recalled to Sweden and he was replaced by Brinkbag. A letter from Svenska Fria Missionen (Swedish Free Mission) at its headquarters in Filadelfia church in Stockholm to the Registrar of Title in Nairobi was very categorical:

We hereby inform you, that Mr Rhode Struble and Mr Gustaf Struble no longer are trustees in the Evangelical Free Mission in Kenya. On September $25^{\text {th }} 1973$ it was decided, that they should be replaced by Oscar Lagerstrom, Harry Sundin, and Helge Westin and we would be very grateful to you if you would register this change. ${ }^{15}$

It is not clear what led to the recalling of Struble, although one may deduce that age was already a key factor since he had just celebrated his $70^{\text {th }}$ birthday. It is clear, however, that during the 1970s a noticeable high number of missionaries arrived in Kenya. Some had formerly worked in countries such as Tanzania, Zaire

11 Letter by Maud Anderson, General Secretary of Evangelical Free Mission in Kenya, to the Registrar of Societies, Nairobi, titled Notification of Dissolution on 26 May 1984.

12 Letter by Maud Anderson, General Secretary of the Evangelical Free Mission in Kenya to the Registrar of Societies in Nairobi, dated 14 July 1995.

13 Letter by Maud Anderson, General Secretary of FPFK, to the Registrar of Societies, Nairobi, titled Notification of Dissolution on 26 May 1984.

14 Rev. Silas Babu, interview by Rev. Edward Mungai, digital recording at FPFK headquarters on 29 October 2014.

15 Letter by Arne Peterson, Secretary of the SFM (Stockholm) to Registrar of Title (Nairobi) on 28 March 1974. 
and Burundi. As a result new work was started in Mombasa and Machakos as well as in Loitokitok. In addition to planting churches, Swedish missionaries found the local communities facing numerous social needs especially in education and health. They became involved in building schools, health facilities and vocational training centres. ${ }^{16}$

Mr and Mrs Arne and Birgit Flordin, fondly nicknamed in Kiswahili as Mama Haraka (swift lady) in reference to her determination to get things done quickly, Mr and Mrs Ingvar and Bibbi Nilsson, Ethel Angerlöf and Anita Boström settled in Mombasa with a mission to do literature and Bible correspondence work. A bookshop, Gospel Centre, was opened in Mombasa in 1974. Church planting also took place and the Likoni church was established in 1974. ${ }^{17} \mathrm{Mr}$ and Mrs Oscar and Märtha Lagerström arrived in Mombasa and later settled in Nairobi, where they worked with Bible correspondence courses as well as church work. Mr and Mrs Alfred and Anna-Lisa Anderson joined them in the Tract Centre, the Bible correspondence work which was now expanding. The table below shows the new missionary arrivals and their distribution in the country.

Table 1: New missionary arrivals and their distribution

\begin{tabular}{|c|c|c|}
\hline Name & Place & Area of work \\
\hline $\begin{array}{l}\text { Maria and Gustav } \\
\text { Struble }\end{array}$ & Nakuru & Church work \\
\hline Eva Danielsson & Nakuru & Church work \\
\hline Einar Karlsson & Nyeri & Church work \\
\hline Ulla Struble & $\begin{array}{l}\text { Nakuru/Mombasa/ } \\
\text { Nairobi }\end{array}$ & Church and literature work \\
\hline $\begin{array}{l}\text { Gudrun and Rhode } \\
\text { Struble }\end{array}$ & Nairobi & Church work \\
\hline $\begin{array}{l}\text { Hildur and Harry } \\
\text { Sundin }\end{array}$ & $\begin{array}{l}\text { Loitokitok, } \\
\text { Machakos, } \\
\text { Mombasa, Malindi }\end{array}$ & Church and literature work \\
\hline $\begin{array}{l}\text { Hildur and Anders } \\
\text { Grönberg }\end{array}$ & Loitokitok & Church work and nursery school \\
\hline $\begin{array}{l}\text { Birgit and Arne } \\
\text { Flordin }\end{array}$ & Mombasa/Kakamega & $\begin{array}{l}\text { Church and literature work as well as } \\
\text { nursery school in Mombasa and Kakamega } \\
+ \text { establishing a vocational training centre } \\
\text { in Kakamega. Built the churches in Likoni, } \\
\text { Mombasa and in Kakamega }\end{array}$ \\
\hline
\end{tabular}

16 FPFK assessment report by Taabco, dated 2013, page 15.

17 Missionary Peter Odak, interview by Rev. David Musumba, digital recording at FPFK headquarters on 29 October 2014. 


\begin{tabular}{|c|c|c|}
\hline Name & Place & Area of work \\
\hline $\begin{array}{l}\text { Saraoch Helge } \\
\text { Westin }\end{array}$ & Machakos & Church work. Built the Machakos church. \\
\hline Karin Larsson & $\begin{array}{l}\text { Thessalia, Nairobi } \\
\text { and Machakos }\end{array}$ & Church and literature work \\
\hline $\begin{array}{l}\text { Märtha and Oscar } \\
\text { Lagerström }\end{array}$ & $\begin{array}{l}\text { Mombasa and } \\
\text { Nairobi }\end{array}$ & $\begin{array}{l}\text { Literature work mainly and some church } \\
\text { work in Nairobi in Kibera, Kawangware and } \\
\text { Embul-bul. Secretary of EFM }\end{array}$ \\
\hline $\begin{array}{l}\text { Mary and Göte } \\
\text { Brinkeback }\end{array}$ & Nakuru & In charge of churches in Nakuru area \\
\hline $\begin{array}{l}\text { Brita and Allan } \\
\text { Lägervik }\end{array}$ & Nairobi and Thika & $\begin{array}{l}\text { Church work in Limuru/Gatundu and } \\
\text { literature work in Thika }\end{array}$ \\
\hline $\begin{array}{l}\text { Birgit and Ingvar } \\
\text { Nilsson }\end{array}$ & Mombasa & $\begin{array}{l}\text { Literature work - responsible for Gospel } \\
\text { Centre }\end{array}$ \\
\hline Anita Boström & Mombasa & Literature work \\
\hline Ethel Angerlöv & Mombasa & Literature work \\
\hline $\begin{array}{l}\text { Ann-Catrin } \\
\text { Sandqvist }\end{array}$ & $\begin{array}{l}\text { Nakuru/Nairobi/ } \\
\text { Goibei }\end{array}$ & $\begin{array}{l}\text { Nursery school work and work within CCEA } \\
\text { (Christian churches Education Association) } \\
\text { training Christian Religious Education } \\
\text { teachers in schools in Nairobi and at } \\
\text { CREATE Goibei }\end{array}$ \\
\hline Gudrun Rosell & $\begin{array}{l}\text { Nairobi/Thika/ } \\
\text { Mombasa }\end{array}$ & Literature work \\
\hline Elaine Åman & Machakos & Church work \\
\hline Maud Anderson & Nairobi & $\begin{array}{l}\text { Keswick Bookshop, ACROSS Sudan, } \\
\text { secretary of EFM and FPFK and business } \\
\text { administrator of FPFK }\end{array}$ \\
\hline Inga-Maj Berggren & $\begin{array}{l}\text { Thika, Nyeri, } \\
\text { Mombasa }\end{array}$ & Literature work \\
\hline Ingalill Bergsten & Loitokitok & Church work \\
\hline $\begin{array}{l}\text { Wendela and Axel } \\
\text { Nission }\end{array}$ & $\begin{array}{l}\text { Nyeri/Mombasa/ } \\
\text { Eldoret }\end{array}$ & $\begin{array}{l}\text { Church work. Built churches in Nyeri and } \\
\text { Eldoret }\end{array}$ \\
\hline Marie-Louise Rask & Mombasa & Literature work \\
\hline $\begin{array}{l}\text { Margareta } \\
\text { Håkanson }\end{array}$ & Nairobi & Keswick Bookshop \\
\hline $\begin{array}{l}\text { Elisabeth } \\
\text { Gustafsson }\end{array}$ & Machakos & Church work \\
\hline $\begin{array}{l}\text { Anna-Greta and } \\
\text { Erling Elgeholm }\end{array}$ & Loitokitok & Church and literature work \\
\hline $\begin{array}{l}\text { Noomi and Dan } \\
\text { Grönberg }\end{array}$ & Loitokitok/Nairobi & $\begin{array}{l}\text { Mobile clinic and construction of Kimana } \\
\text { Secondary School and Kawangware church }\end{array}$ \\
\hline
\end{tabular}




\begin{tabular}{|c|c|c|}
\hline Name & Place & Area of work \\
\hline Karin Hansen & Loitokitok & Mobile clinic \\
\hline Lilly Nedergård & Loitokitok & Mobile clinic \\
\hline $\begin{array}{l}\text { Ingela and Hans } \\
\text { Sundström }\end{array}$ & Loitokitok & Mobile clinic \\
\hline $\begin{array}{l}\text { Mia and Arne } \\
\text { Peterson }\end{array}$ & $\begin{array}{l}\text { Karen Bible School, } \\
\text { Nairobi }\end{array}$ & Principals of Karen \\
\hline $\begin{array}{l}\text { Anna-Lisa and } \\
\text { Alfred Anderson }\end{array}$ & $\begin{array}{l}\text { Nairobi and } \\
\text { Machakos }\end{array}$ & Church work and Tract-Centre \\
\hline $\begin{array}{l}\text { Robbie and Per- } \\
\text { Arne Peterson }\end{array}$ & Karen Bible School & Ass. Principal \\
\hline $\begin{array}{l}\text { Gertrud and Stig } \\
\text { Gustavsson }\end{array}$ & Nairobi & Church work. Built Kawangware church \\
\hline $\begin{array}{l}\text { Kerstin and Seth } \\
\text { Lindström }\end{array}$ & Karen Bible School & Principal of Karen \\
\hline $\begin{array}{l}\text { Maria och Kimmo } \\
\text { Katisko }\end{array}$ & Kakamega & Kakamega Polytechnic \\
\hline Välikanga family & Kakamega & Kakamega Polytechnic \\
\hline $\begin{array}{l}\text { Solveig and Willy } \\
\text { Alestand }\end{array}$ & Kakamega & Kakamega Polytechnic \\
\hline $\begin{array}{l}\text { Ann-Mari and Per- } \\
\text { Åke (Pelle) Nilsson }\end{array}$ & Nyeri/Nairobi & $\begin{array}{l}\text { Church work and Principal Karen Bible } \\
\text { School }\end{array}$ \\
\hline $\begin{array}{l}\text { Vivianne and Hans } \\
\text { Sandström }\end{array}$ & Nairobi & Keswick Bookshop \\
\hline Gunilla Larsson & Nairobi & Keswick Bookshop \\
\hline $\begin{array}{l}\text { Maggie and Åke } \\
\text { Sandström }\end{array}$ & Nairobi & Tract-Centre \\
\hline $\begin{array}{l}\text { Mirja and Stig } \\
\text { Jacobsson }\end{array}$ & Mombasa & $\begin{array}{l}\text { Church work Likoni, Ukunda and Shimba } \\
\text { Hills }\end{array}$ \\
\hline $\begin{array}{l}\text { Tess and Anders } \\
\text { Erixon }\end{array}$ & Nairobi & $\begin{array}{l}\text { Project leaders for preschool and women } \\
\text { training centres }\end{array}$ \\
\hline $\begin{array}{l}\text { Ingalill and Anders } \\
\text { Riedenfalk }\end{array}$ & Nairobi & $\begin{array}{l}\text { Inga-Lill: Project leader for preschool and } \\
\text { women training centres } \\
\text { Anders: PMU scholarship programme }\end{array}$ \\
\hline $\begin{array}{l}\text { Christine and Gert } \\
\text { Bennevall }\end{array}$ & Nairobi & $\begin{array}{l}\text { Project leaders preschool and women } \\
\text { training centres }\end{array}$ \\
\hline $\begin{array}{l}\text { Barbro and Arne } \\
\text { Wallhäger }\end{array}$ & Nairobi & $\begin{array}{l}\text { Church work and development of training } \\
\text { materials for preschool teachers }\end{array}$ \\
\hline $\begin{array}{l}\text { Idemaj and Rolf } \\
\text { Oldin }\end{array}$ & Nairobi & House parents at Kindaruma Boarding \\
\hline
\end{tabular}




\begin{tabular}{|l|l|l|}
\hline Name & Place & Area of work \\
\hline $\begin{array}{l}\text { Marie and Staffan } \\
\text { Wreland }\end{array}$ & Nairobi & House parents at Kindaruma Boarding \\
\hline $\begin{array}{l}\text { Inger and Torbjörn } \\
\text { Stedt }\end{array}$ & Nairobi & House parents at Kindaruma Boarding \\
\hline
\end{tabular}

\section{THE GREAT CONTROVERSY OVER STRATEGIC DIRECTION}

Early 1973, Swedish Missionaries met in YMCA in Nairobi. The key agenda of the meeting was to resolve a raging debate on whether Swedish missionaries should be involved in planting local churches. According to Maud Anderson 'the decision in Sweden was then not to found churches, since Kenya had so many registered Pentecostal Missions. Instead they preferred to join one of them, which was the Pentecostal Assemblies of God (PAG), Valley Road church Nairobi'. ${ }^{18}$ Indeed, the intention of some of the missionaries as well as contact churches such as that in Linköping, strongly felt that at this stage the priority was not to plant churches in major cities but to work with literature distribution and Bible correspondence courses and to support other local mainstream Pentecostal churches such as the Nairobi Pentecostal church (NPC). This was compounded by the fact that the EFM constitution did not allow it to own property and establish churches.

This created tension within the missionaries and the EFM since a good number of missionaries felt called to establish churches. ${ }^{19}$ Leadership crises erupted and the situation became so severe that in 1974, 12 Swedish pastors representing the Swedish churches with work in Kenya attended the EFM annual conference held in September at Brackenhurst, Limuru. The meeting was intended to decide on leadership issues as well as bring about reconciliation between missionaries and set out a strategy for future work. The meeting was attended by a large delegation from Sweden. It was then agreed that church work could be established. At the meeting, it was resolved that the EFM will be involved in founding local churches and that the constitution was to be amended to incorporate the agreed decision. ${ }^{20}$ The Swedish delegation appointed Mr Oscar Lagerström to be secretary of the Evangelical Free Mission, which he accepted with the condition that Maud Anderson, who had arrived

18 Maud Anderson, interview by Rev. Edward Mungai and Stephen Muoki, digital recording at FPFK Kindaruma Guest House on 7 December 2014.

19 Stephen Muoki Joshua, The interface between 'Missionary' and 'National' theological education in the Free Pentecostal Fellowship. In Kenya: A historical perspective, Studia Historiae Ecclesiasticae, December 2006 XXXII(3): 173-191.

20 Letter written by Secretary, Deputy Secretary and Deputy Vice Secretary of the SFM in Kenya on the subject, Re: Changes of Name and Constitution, nd. 
in 1973, would be his assistant. ${ }^{21}$ This position was later taken over by Mr Allan Lägervik through ballot, the successor of whom was Ms Maud Anderson and in 1993 Rev. Edward Mungai.

Following the above meeting, the EFM was registered with the Land Office and given a certificate of incorporation with the legal right to own property. Many more churches were constructed. Ms Karin Larsson, who had worked with the Norwegian Pentecostal Mission in Thessalia since 1964, moved to the SFM in Nairobi and later to Machakos, where she worked with Ms Gudrun Rosell. Later Ms Inga-Maj Berggren joined Rosell and they eventually moved to Thika, Nyeri and later to Mombasa, where they were involved in literature work. Ms Marie-Louise Rask joined the literature work in Mombasa. Ms Inga-Lill Berggren joined in 1974 and went to Loitokitok and Elaine Åman arrived and settled in Machakos to join Mr Helge and Sara Westin in church planting work. Elisabeth Gustafsson worked with Elaine Åman for some time in Machakos. Elaine Åman was later called to train Sunday school and youth workers in the country.

In Loitokitok Mr and Mrs Harry and Hildur Sundin began work, which was later taken over by Mr and Mrs Anders and Hildur Grönberg. Mr and Mrs Erling and Anna-Greta Elgeholm also worked in Loitokitok for a shorter period. ${ }^{22}$ Ms Anki Sandqvist came to Kenya in 1973 and first worked in Nakuru with the youth and became involved with children's work as well as being a volunteer CRE teacher in high schools. She later became the assistant director of Christian Religious Education Awareness for Teachers (CREATE), where hundreds of primary school teachers have been offered in-service courses in Christian Religious Education (CRE) ${ }^{23}$

In the early 1970s, communist ideals led to a change in Tanzanian land policy. As a result, a number of missionaries moved over the border from Tanzania to join the work in Kenya. Among them were Mr and Mrs Göte and Mary Brinkeback who settled in Nakuru, and Mr and Mrs Axel and Wendela Nilsson who settled in Nyeri and later moved to Mombasa and Eldoret. ${ }^{24}$

Several churches were built during this period, among them the Likoni church in Mombasa (1974), built by Arne and Marie-Anna Flordin and opened in 1976, as well as Nyeri, built by Axel Nilsson, and opened in 1979. ${ }^{25}$ Church plots were acquired, certificates were applied for and approved and title deeds were issued in

21 Rev. Willy Munene, interview by Rev. Edward Mungai, digital recording at FPFK headquarters on 30 October 2014.

22 Rev. Peter Odak, interview by Rev. David Musumba, digital recording at FPFK headquarters on 29 October 2014.

23 Rev. David Ford, interview by Rev. Edward Mungai, digital recording at FPFK headquarters on 30 October 2014.

24 Rev. Peter Odak, interview by Rev. David Musumba, digital recording at FPFK headquarters on 29 October 2014.

25 FPFK Organizational Documents, The Constitution and rules doc. 001. Nairobi, Uzima Centre, $2001,1$. 
EFM names. ${ }^{26}$ Indeed, it was during this time of great controversy and increased missionary activity that the church grew most. This is evidenced by the brief annual report for the FPFK presented by the General Secretary, Maud Anderson in 1984. It in part read as follows:

It is with much gratitude to the Lord that we look back on the year 1984 and for the many blessings that he has bestowed upon us as individuals and as a fellowship. It is with joy that we note that many people have received the Lord Jesus as their personal Saviour and been added to our churches country-wide. Full statistics have not been received for the year 1984, but the church membership was approximately 30000 with around 300 pastors and evangelists and 50 missionaries. One of the significant happenings during the year 1984 was the merger of the Free Pentecostal Fellowship in Kenya, originating from Norway and the Evangelical Free Mission in Kenya, originating from Sweden, which took place on $26^{\text {th }}$ May 1984 at Karen and which led to the strengthening of our work in Kenya. The FPFK committee, elected at the above meeting, has met three times during the year. May the Lord continue to bless his people and may many more commit their lives to service for Him before He returns. ${ }^{27}$

A new constitution was worked out and it was decided that the EFM registration should only include Swedish missionaries and that each local church should have its own registration according to the Swedish (biblical) system. This was, however, refused by the Office of the Registrar and the constitution had to be amended to include the national churches. The new constitution was accepted at an AGM and later communicated to all churches through an intensive visiting programme by Ms Maud Anderson and Mr Edward Mungai and other national leaders. ${ }^{28}$

\section{SWEDISH FREE MISSION EARLY PROJECTS IN KENYA}

In 1973 Mary Smythe of Keswick Book Society, in consultation with Lagerström, made a request that the Swedish Mission takes over the bookshop. This was done officially in 1974. Mr Allan Lägervik was requested to be the new manager ${ }^{29}$ after Ms Mary Smythe. The handover to Lägervik, however, did not materialise. Meanwhile Margareta Håkansson had arrived in Kenya in 1974 as an assistant and was left with the shop until a new manager, Mr Hans Sandström from the USA arrived. Mr

26 Maud Anderson, interview by Stephen Muoki, digital recording at FPFK headquarters on 7 December 2014.

27 Maud Anderson, A Brief Annual Report for the Free Pentecostal Fellowship in Kenya 1984, Karen Head Office, 1984.

28 Letter written by the General Secretary of FPFK, Maud Anderson to the Registrar of Societies on the subject, Re: Registration of Evangelical Free Mission in Kenya - Reg. No. 4615, on 14 July 1995.

29 Joseph Ayieye and Vigdis Gjervoldstad, Church Leaders Seminar: Leadership FPFK Structure Management FPFK Capacity Building Programme, OD \& CB project manual, Nairobi, 1999, 4. 
Sandström and family only stayed for one year and Margareta Håkansson became the new manager and stayed until 2012. Maud Anderson was the assistant manager for some years until she became full-time General Secretary. The Gospel Centre in Mombasa was incorporated with Keswick.

The Tract Centre expanded and Mr and Mrs Åke and Maggie Sandström joined the work. In 1975 Swedish churches decided to fundraise aggressively for Kenya to raise one million Swedish Kronor. These funds were meant to buy a property in the middle of Nairobi. That later fell through but the funds were used for building churches and providing churches with mabati roofs (iron roofing sheets). The Flordins later moved from Likoni to Kakamega as church planters and in the beginning of the 1990s a carpentry training school was started with PMU/SIDA support. They were joined by Mr and Mrs Välikangas and the Kimmo Katisko family who built up the school and started the training programme. They were later replaced by $\mathrm{Mr}$ and $\mathrm{Mrs}$ Willy Alesand as teachers of the school. Mr and Mrs Stig and Gertrud Gustafsson arrived in Nairobi to join the church work and were instrumental in building the first permanent church in Kawangware with the help of Dan Grönberg. ${ }^{30}$

The first PMU/SIDA financed project was Kimana Secondary school, Loitokitok, which was built in the 1980s by Mr Dan Grönberg. ${ }^{31}$ A mobile health clinic was run in Kajiado by Karin Hansen, Lilly Nedergård, Hans and Ingela Sundström as well as Noomi Grönberg before being handed over to national staff. Due to Mr Lagerström's return to Sweden, Mr Lägervik was chosen to be the new secretary and moved to Nairobi. He was also involved in Bible correspondence work and church planting in Limuru and Gatundu, after having started a Christian bookshop in Thika. After a time he left for Sweden and Maud Anderson as his assistant took over and was later elected as General Secretary for a number of years until 1993 when Edward Mungai took over, followed by Julius Bagaka in 1996.

\section{SPECIFIC SWEDISH FREE MISSION CHURCHES IN KENYA AND THE WORK OF AFRICAN CHURCH PASTORS}

Missionary Gustav Struble (of SFM) visited Nyeri several times starting from 1961 and met with many preachers (not from the Swedish Mission) who were willing to join him in his mission work. Some of those he met were Willie Munene, Ananiah Mwangi and Gerald Muteru. ${ }^{32}$

30 AGM Minutes of FPFK Minutes, 1991, 2.

31 FPFK, Extracts of Minutes taken at the Annual General Meeting of the Free Pentecostal Fellowship in Kenya on May 26 May 1984 at Karen.

32 Gerald Muteru, interview by Stephen Muoki Joshua, digital recording at FPFK headquarters on 30 October 2014. 
Willie Munene, who hailed from Kihome church, later opened a church in north Kinangopat Karima after joining Gustav Struble. He settled there and continued pasturing the church. ${ }^{33}$ Ananiah Mwangi was a businessman before joining Gustav Struble, located at Nanyuki. He owned a dry-cleaning company which was known as Seven Stars Drycleaners. He met Gustav Stublein Nyeri in 1963 in a hotel known as Outspan Hotel, and decided to work together for the Lord under the SFM. In 1964, Struble sent him to Huhoini church to work with Muteru. Later the missionary asked him to choose to serve either the church or his dry-cleaning business. He chose to serve the Lord. ${ }^{34}$ In 1971 Gustav Struble, who was nicknamed Kamunyu (means 'one who uproots' in a local dialect) transferred him to Menengai church where he stayed for three months only. He was uprooted and sent to Solai, Nakuru. ${ }^{35}$

Gerald Muteru was a member of the Anglican Church before he joined the SFM. In 1964 he started preaching at Huhoini. His salary was 50 shillings per month. He had to quit preaching for a while in order to construct a house because he wanted to marry. He went to Struble to ask for help to enable him to marry. Struble gave him 10 shillings only. He was very discouraged but went on working with Struble. He completed his house and married in 1965. He continued ministering and opened several branches. ${ }^{36}$

Missionaries Maria and Gustav Struble, together with local pastors Gerald Muteru, Ananiah Mwangi and Willie Munene, planted several churches in the area around Mt Kenya and beyond under the flag of the SFM. Some local churches are Kihome church (built in 1960 which was built permanently in 1963), which has a branch at Tetu, Huhoini in 1964 (permanently built in 1978), and Munyange in 1966. These churches have several branches. ${ }^{37}$

The Maasai church was abnormally born through the work of an African missionary, from the Luo community, by the name of Peter Odak. With the help of Swedish missionaries he pioneered Rombo church as well as its immediate branches in Loitoktok, Illacit and Kimana. ${ }^{38}$ Later on he pioneered work at the coastal region with Likoni and Lamu (Mpeketoni) being the earliest churches.

33 Willy Munene, interview by Rev. Edward Mungai, digital recording at FPFK headquarters on 30 October 2014.

34 Anania Mwangi, interview by Rev. Edward Mungai, digital recording at FPFK headquarters on 29 October 2014.

35 Anania Mwangi, interview by Rev. Edward Mungai, digital recording at FPFK headquarters on 29 October 2014.

36 Gerald Muteru, interview by Rev. Edward Mungai, digital recording at FPFK headquarters on 29 October 2014.

37 Anania Mwangi, Willie. Menene, Gerald Muteru, interview by Edward Mungai, digital recording at FPFK headquarters on $29 \& 30$ October 2014.

38 Rev. Daniel Kisemei, interview by Stephen Muoki Joshua, digital recording at FPFK headquarters on $29 \& 30$ October 2014. 


\section{MENENGAI AND NORTH KINANGOP CHURCHES}

When missionary Gustav Struble made a trip to Nyeri in 1962, he met Mr Olsen, a Norwegian missionary (not of the FPFK) working there and Pastor Willie Munene, who was already pastoring a church at Kihome under missionary Olsen. When Struble, Olsen and Munene met they agreed that Munene could join Struble as his work mate. It was from that time that Willie Munene joined Gustav Struble. ${ }^{39}$ Therefore, Willie Munene continued pastoring his church at Kihome whilst visiting the Menengai church from time to time to preach and baptise. Struble, though still stationed at Menengai, started supporting the Kihome church together with its Kikuyu pastor.

In the same year, 1962, Willie Munene together with Daniel Macharia opened another branch church at North Kinangop - Karima. North Kinangop is situated at the foot of the Aberdare ranges. It is located in between Nyeri and Menengai. Macharia later left Munene as the pastor in this church and he has continued to pastor the church up to date. According to Munene, the church was born during his several pastoral trips between his home church - Kihome (Nyeri) and Menengai church (Nakuru). ${ }^{40}$ Munene used the bicycle, which he was given by a certain missionary (that was after attending a Bible course in Mombasa and before joining the SFM which was led by Struble), to commute between Nyeri and Menengai via Kinangop during his pastoral work. On his $70^{\text {th }}$ birthday celebration, Gustav received gifts in cash which he used for the construction of Karima church - North Kinangop. ${ }^{41}$ Munene, together with late Simon Ngechu, opened another branch at a place called Engineer in 1964.

Rhode and Ulla Struble, son and daughter of Maria and Gustav Struble, came to Kenya in 1965 to join their parents in missionary work. Rhode Struble headed for Nairobi to plant churches there, while Ulla Struble remained in Nakuru. In the same year Gustav Struble, accompanied by evangelist Japheth, pioneered a church in Rongai. Another one was opened in Bukura, Kakamega by Anderea Opuka in 1965. Duncan Kariuki opened a branch church at Ndundori in 1965. Daudi Muriuki moved to Solai in 1968 and opened another branch of Menengai church. Ulla, Marko and John Mathiaka started evangelistic work in Nakuru town. David Ford, a Kamba local pastor and a convert from Rongai church, joined them later. Their evangelistic endeavour resulted in the birth of Langalanga church in Nakuru town in 1969. In the same year Josiah Waitindi and Mama Kasisi opened a branch in Elementaita. ${ }^{42}$ Several churches were opened in the Nakuru area between 1969 and before Maria

39 Pastor Willie Munene, interview by Rev. EM. Mungai at FPFK headquarters on 29 October 2014.

40 Pastor Willie Munene, interview by Rev. EM. Mungai at Karima church - north Kinangop on 12 March 2015.

41 Maud Anderson, interview by Rev. EM. Mungai at FPFK headquarters on 7 December 2014.

42 Anania Mwangi, interview by Rev. Edward Mungai, digital recording at FPFK headquarters on 29 October 2014. 
and Gustav Struble left in 1974. Among them are Gatura and Kabazi churches in 1969.

Rhode Struble later moved to Nairobi. He bought a house along Hatheru Road, off Gitaga Road, off James Gichuru Road in Nairobi. This house, which was popularly known as Sjionsborg, became a house of residence for Swedish missionaries. The house was sold in the 1990s in order to purchase the Kindaruma property which is currently the headquarters of FPFK. Ananiah Mwangi was transferred to Menengai in 1971 by Gustav and later to Solai. Joseph Chege opened Limuru church in 1973 after leaving North Kinangop where he was working. ${ }^{43}$ Longonot church was opened by Willie but handed to Limuru in 1975. Githuya church and Gatundu church were opened in 1975 by Limuru church.

Missionaries Brita and Allan Lagervik joined Limuru church in 1976. They played a major role in the construction of the first semi-permanent church building. Lagervik was one of the open-minded missionaries and would speak openly on anything that he did not like in church. Sometimes he would say that he did not like the church beating the local drums when singing. Elders would answer him that the drums were the only musical instruments they had to co-ordinate singing. The elders would jokingly challenge him to buy the church modern musical instruments like a piano and guitars. Lagerviks left Limuru early in $1979 .{ }^{44}$

The other church planting missionaries who worked in Limuru were Magi and Ake Sandstrom in the 1980s. They joined the church in construction of the new permanent church in Limuru town. The two families, the Lagerviks and Sandstroms, hailed from a town known as Karlskoga in Sweden - the home of Alfred Nobel the initiator of the Nobel Price Foundation. ${ }^{45}$ After the departure of missionaries Maria and Gustav Struble in 1974, their daughter Ulla Struble was left working at Langalanga church in Nakuru. Meanwhile, missionaries Mary and Gote Brinkebark arrived in Nakuru in 1975 and took over the entire missionary work. During his time new churches were opened in different places in Nakuru. Timboroa church under Pastor Daniel Waweru as well as London church, Free Area, and Jogoo church under Pastor Philip Maina, were opened in 1975. Others were opened between 1976 and 1978, such as: Kipkelion church under Pastor Daniel Waweru; Molo church under Pastor John Murimi; Njoro church under Pastor Anania Mwangi; Kedowa church under Pastor Yohana Gitau; and Kitale church under Pastor Elijah Ejore. ${ }^{46}$

43 Willy Munene, interview by Rev. Edward Mungai, digital recording at FPFK headquarters on 30 October 2014.

44 Anania Mwangi, Willie. Menene, Gerald Muteru, interview by Edward Mungai, digital recording at FPFK headquarters on $29 \& 30$ October 2014.

45 Rev. EM. Mungai, interview by Rev. Musumba at FPFK headquarters on 30 October 2014.

46 Anania Mwangi, David Ford, Peter Muya, John Murimi et al., interview by Edward Mungai, digital recording at FPFK headquarters on 29 October 2014 


\section{NYERI 1960 (KIHOME CHURCH)}

The arrival of a new family of missionaries - Axel and Wendela Nilsson in Nyeri in 1974 - brought more growth and expansion of the church. The Nilssons settled in Nyeri town and together with local pastors led by Pastor Gerald Muteru, pioneered other new local churches including the one in Nyeri town pastured by Gerald Muteru and built in 1975. Others were the Micha church built in 1978, Gitugi in 1982, Kairuthi, Wachara, and Kigonye branches. Nilsson was a builder who ended up building several churches, including the church in Nyeri town and Huhoini. ${ }^{47}$

\section{ROMBO CHURCH 1964}

The story of Rombo church is closely intertwined with the life and ministry of Peter Odak. Peter Odak converted to Christianity on 23 June 1957 at Tononoka grounds in Mombasa city, following an evangelistic open-air preaching by a visiting American evangelist by the name of T.L. Osborn. ${ }^{48}$ By that time, he was working with the East African Railways and Harbours. He was 18 years old. In 1958 he was transferred to go and work in Dar es Salaam. While in Tanzania, he met a Swedish missionary by the name of Axcel Burman. He started working as a missionary under Burman and resigned from the railways in 1959. He was sent for a three month ministerial course in Kigoma, Tanzania. In 1962 he was transferred to Marangu, Tanzania, to work under missionary Brink Berk who sent him to Puge Bible School in Tabora. It was while at the Puge Bible School that he "twice saw a vision of two people dressed in Olkaria, Maasai red Moran attire, calling him to cross over and go to them' ${ }^{49}$ When he shared his experience with Axcel Burman, a Swedish principal of the Bible School at Puge, Axcel explained that 'God was certainly calling him to evangelise the Maasai people'. In 1963 he finished the Bible school training and went to Marangu to serve as an Evangelist in the area around Lake Jipe. There he worked under missionary Brink Berk, who later requested him to go to Rombo Mkuu to help some missionaries in interpretation. At Rombo Mkuu he worked with missionary Harry Sundin for one year, opening churches within the Rombo Mkuu district under the SFM. Two Maasai Morans who had come from Kenya converted to Christianity. Their names were John Ole Kaiakon and William Ole Tipape. He sent them back to Kenya as witnesses of the Christian message. Whereas Odak felt called to serve among the Rombo Maasai in Kenya, Sundin was opposed to this move stating that 'God sent them to Rombo Tanganyika not Kenya'. Odak explained as follows:

47 Gerald Muteru, interview by Edward Mungai, digital recording at FPFK headquarters on 29 October 2014.

48 Rev. Peter Odak, interview by Stephen Muoki Joshua, digital recording at FPFK headquarters on 29 October 2014.

49 Rev. Peter Odak, interview by Stephen Moki Joshua on 29 October 2014. 
I told him that it was a divine call from God to go and serve at Rombo Kenya up Loitokitok. He was not pleased with the vision that I had. This mission brought misunderstanding between me and the churches at Marangu and Rombo Mkuu in Tanzania which we founded together with Sundin. I was hated by the missionaries and the pastors. When I was praying, God told me to arise and go. He told that he had prepared the Maasai's to take care of me. After one month, I got three Maasais who came from Rombo Mkuu Kenya to visit us at Rombo Mkuu Tanzania. They were William ole Tipape, Stephen Nyatia, Tabitha, Nyatia's wife. They asked me to go and help them and not leave them as orphans. That confirmed to me the vision that God had given to me..$^{50}$

Eventually Odak relocated to Rombo, Kenya in 1964 to work among the Maasai. Consequently, the missionaries withdrew their support for him. However, Maasai people gave him memorable support. The earliest converts were Mzee Ngong'oni in Ngarareni, John Kaiako in Rombo, and Mzee Orubetwi who was miraculously healed and provided Odak with accommodation. Ole Kinyala, a new convert, gave him a goat which he sold in order to finance transporting of his property to Kenya in Rombo. He started the first church there in 1965. Mr Swahili, a Maasai who was a brother of Koolio, sold them 10 iron sheets which they used to construct the first church in Rombo.

The church in Rombo grew speedily despite very real challenges. First, Odak was regularly arrested by local authorities on accusation that he was collaborating with whites to hunt for wild animals in Amboseli Game Reserve. The second major challenge was opposition by white missionaries based in Tanzania. His efforts in search of a supporting missionary in Sweden were frustrated by Swedish representatives across the border. He reported as thus:

Accusation was made against me and my host Orubetwi that we were killing wild animals that were under game reserve. I was caught and taken to police cell in Loitokitok, there was nothing found to prove that I was guilty of the offence. They went ahead and forged another case against me. They claimed that I entered the game reserve without poll tax and local rates. I sent Ntaiya to go into my house and bring me the receipts for the taxes. I was later released. I entered into prayer and fasting for three days for God to connect me with missionaries who could help me do the work. After five days I went to Marangu to see Clyberg who was a missionary and showed him the burden I had in the work. He asked me to write a letter of request to the missionaries so that he could take it to Sweden. He took my letter and came back with the reply after 3 months. I was asked to go to Tabora to meet the visitors from Sweden so that I can share with them what was in my heart. I trusted God for means to reach Tabora, God touched Mzee Olekinyala whose wives were members of the church to give a goat to each of them. I sold the goats and got the means of reaching Tabora. I was chased by the missionaries, and the visitors that I was going to meet postponed their coming. When I reached Arusha I ran short of money, this made me to walk for a long distance of over 50 miles to reach Moshi where I spent the night in the house of Evangelist

50 Rev. Peter Odak, interview by Stephen Muoki Joshua, digital recording at FPFK headquarters on 29 October 2014. 
Geoffrey. The following day I sold my goat to get means of reaching Rombo Useri and I managed to reach home. ${ }^{51}$

In 1967 Odak wrote another letter to Sweden telling them how he got chased by the missionaries in Tabora who said they could not support the work in Kenya. Four months later he got a reply. They were sorry for not coming as they had promised, partly due to local politics and election processes. ${ }^{52}$ However, they offered to meet him in Dar es Salaam in August at a conference. Odak brought many Maasai gifts and gave report of his work among the Maasai in Kenya. As a result, and to the surprise of Odak, Missionary Harry Sundin was sent to work with Odak in Rombo Kenya. Apparently, Sundin was also unhappy with the changes in land policy in Tanzania following the downfall of the Ujamaa socialist system. In his own words, Odak argued that although Sundin 'formally opposed my coming to Kenya, God caused him to join me. His coming enhanced the growth of the church and ministry at large as recorded in the book of Acts $2: 47, .53$

While in 1967 Sundin went back to Sweden to look for official documentation to work in Kenya, Odak applied for a plot at Rombo when the demarcations of land were being done. Joshua Sikembei, the son of Isiah Partei (Lemoriati) who was doing the work of demarcation, was very supportive and the SFM was allocated a 20 acres plot of land. It was on this land that Sundin built the church and the pastor's house in 1969. On 20 August 1969, the church was opened officially by a pastor from Sweden by the name Loger Christ, and the very same day a request was made for the building of a secondary school in Maasai land. In 1972 missionary Andres Gronberg replaced Harry Sundin in a hand-over ceremony conducted on 25 December. Sundin left for Malindi. A plot of land was acquired in Kimana and a secondary school was built there between 1982 and 1984 by missionary Andres Gronberg and his son Dan Gronberg. Its first headmaster was Mr Solomon Kiunga. ${ }^{54}$

Many more branches were opened and more ministers joined Odak in the work. Over the years, the Rombo church raised up pioneer pastors in the FPFK. Evangelist Paul Bondo and Daniel Njoroge, and later Antanas Mwaura, joined Odak in 1972. In 1973, on 20 May, Daniel le Kisemei was brought by Antanas from the PCEA church. At that time Anderson Gronberg was the missionary. In 1975 Daniel Kisemei brought Daniel Osoi but he did not want to work at Loitokitok. He had a burden of working at Emali. Christopher Sipaya also was among the youth converts who got saved and spiritually grew in the church foundation. God had prepared this for future

51 Rev. Peter Odak, interview by Stephen Muoki Joshua, digital recording at FPFK headquarters on 29 October 2014.

52 Kenya and Tanzania got independence from Britain in 1964.

53 Rev. Peter Odak, interview by Stephen Muoki Joshua, digital recording at FPFK headquarters on 29 October 2014.

54 Rev. Daniel Kisemei, interview by Stephen Muoki Joshua, digital recording at FPFK headquarters on $29 \& 30$ October 2014. 
ministry as God's servant in Entara and his ministry has totally developed. Pastor John Parteiye also got saved when he was young and has grown in church. As a result, churches were established in Entara (1967), in Loitoktok (1970, Illacit (1976) and in Kimana (1979).

Table 2: $\quad$ Record of established Swedish Free Mission churches

\begin{tabular}{|c|c|c|c|}
\hline Mission Centre & Branch church & $\begin{array}{l}\text { Date of } \\
\text { establishment }\end{array}$ & Founding Pastor/Evangelist \\
\hline \multirow{20}{*}{$\begin{array}{l}\text { Nakuru } \\
\text { Gustav Struble, } \\
\text { Brigbag }\end{array}$} & Menengai & 1960 & $\begin{array}{l}\text { Gustav Struble and Ev. } \\
\text { Munyasia }\end{array}$ \\
\hline & $\begin{array}{l}\text { North Kinangop/ } \\
\text { Karima }\end{array}$ & 1962 & Willy Munene \\
\hline & Bukura & 1965 & Andrea Opuka \\
\hline & Rongai & 1965 & Japheth \\
\hline & Elementaita & 1969 & Josiah Waitindi/Kasisi Mama \\
\hline & Langalanga & 1969 & $\begin{array}{l}\text { John Mathiaka, Marko, } \\
\text { Japheth, David Ford }\end{array}$ \\
\hline & Solai & 1968 & Daudi Muruki \\
\hline & Limuru & 1973 & Joseph Chege \\
\hline & London & 1975 & \\
\hline & Ndonduri & 1965 & Duncan Kariuki \\
\hline & Timboroa & 1974 & Kahiga/Daniel Waweru \\
\hline & Free Area & 1975 & \\
\hline & Jogoo & 1975 & Phillip Maina \\
\hline & Gatundu & 1976 & Joseph Chege \\
\hline & Longonot & 1976 & $\begin{array}{l}\text { Willy Munene/Joseph Chege/ } \\
\text { Edward Mungai }\end{array}$ \\
\hline & Kabazi & 1976 & Peter Muya \\
\hline & Kipkelion & 1976 & Daniel Waweru \\
\hline & Molo & 1977 & John Murimi \\
\hline & Kedowa & 1978 & Yohana Gitau \\
\hline & Kitale & 1977 & Elijah Ejore \\
\hline \multirow{7}{*}{$\begin{array}{l}\text { Loitoktok } \\
\text { Missionary } \\
\text { Sundin }\end{array}$} & Rombo & 1965 & Missionary Peter Odak \\
\hline & Entarara & 1966 & Christopher Sipaya \\
\hline & Loitoktok & 1968 & Paul Obodo \\
\hline & Illasit & 1972 & \\
\hline & Kimana & 1974 & \\
\hline & Namanga & & \\
\hline & Emali & 1975 & \\
\hline
\end{tabular}




\begin{tabular}{|c|c|c|c|}
\hline Mission Centre & Branch church & $\begin{array}{l}\text { Date of } \\
\text { establishment }\end{array}$ & Founding Pastor/Evangelist \\
\hline \multirow{7}{*}{$\begin{array}{l}\text { Nyeri } \\
\text { Missionaries } \\
\text { Pexil Nilson }\end{array}$} & Kihome & 1960 & Willy Munene \\
\hline & Uhoini & 1964 & Gerald Muteru \\
\hline & Munyange & 1966 & Joseph Taiti \\
\hline & Kairuthi & & \\
\hline & Kanyinyaini & & \\
\hline & Micha & & \\
\hline & Gitugi & & \\
\hline \multirow{5}{*}{$\begin{array}{l}\text { Mombasa } \\
\text { Missionary } \\
\text { Flordin and Stigg } \\
\text { Jacobson }\end{array}$} & Likoni & 1972 & \\
\hline & Mpeketoni & 1974 & Peter Odak \\
\hline & Ukunda & & Mwangangi/St \\
\hline & Kinango & & Solomon Masunzu \\
\hline & Taveta & & Simon Mutisya \\
\hline \multirow[t]{7}{*}{ Nairobi } & Gikambura & 1972 & $\begin{array}{l}\text { Winnie Njeri/Rhode and Ulla } \\
\text { Struble }\end{array}$ \\
\hline & Kawangware & 1974 & $\begin{array}{l}\text { Miss Rhodes Struble, Paul } \\
\text { Kamau }\end{array}$ \\
\hline & Kibera & & Peter Sudhe \\
\hline & Thogoto & & \\
\hline & Dagoreti & 1980 & $\begin{array}{l}\text { Johnson Macharia/ Ake } \\
\text { Sandstrom }\end{array}$ \\
\hline & Embulbul & 1977 & Gjervoldstad/Koyando \\
\hline & Eastleigh & 1976 & Koyando/Gjervolstad \\
\hline \multirow{7}{*}{$\begin{array}{l}\text { Machakos } \\
\text { Missionary } \\
\text { Sundil, Westina, } \\
\text { Hellena and } \\
\text { Elizabeth }\end{array}$} & Kithaayoni & 1967 & $\begin{array}{l}\text { Missionary Sundil/Samuel } \\
\text { Kamau }\end{array}$ \\
\hline & Mitaboni & 1968 & \\
\hline & Makindu & 1975 & \\
\hline & Mithanga & 1976 & \\
\hline & Tunguni & 1977 & \\
\hline & Nzaikoni & 1977 & \\
\hline & Muumandu & 1980 & \\
\hline
\end{tabular}

\section{LIKONI AND MPEKETONI CHURCHES AT THE COAST}

\section{Mpeketoni}

In 1973 the government of Kenya initiated a settlement scheme in Mpeketoni, Lamu. At the same time, Tanzania started a socialist regime and the consequent Ujamaa 
villages. A group of Kenyans consisting of mainly Kikuyus, Kambas and Luos who had moved into Tanzania near Kilimanjaro, were displaced on account of Ujamaa villages. As a result, the Kenyan government resettled them in the newly established settlement scheme in Lamu. They were given 10 acres per person and provided building materials. ${ }^{55}$

There were believers from SFM churches in Rombo Mkuu in Tanzania who migrated to the area to look for land in 1974. These included Mzee Gaithonga and his family, Mzee Gogoand his family, Andrea Onyach, Mzee John Mbuthia (Wanyange and his family), teacher Dickson Kamau and his family and others. There was a need to organise them into a church. Peter Odak and missionary Gronberg made several trips there and soon the church was up and running. Joseph Karanja was the first pastor of the church.

\section{Likoni}

Peter Odak and missionary Sundin conducted an evangelistic crusade in Likoni in 1970. However, it was difficult to start a church due to lack of personnel and the fact that it was far from Loitokitok. Two years later a new missionary, Flodin, and other sisters came and started by opening a Christian bookshop and the first student was found, that is Morris Arao, who was later employed to sell books in the shop and serve as an evangelist. The second student was Joseph Karisa. ${ }^{56}$ In 1974 Athanus Mwaurawas sent from Loitoktok to Mombasa to help Flodin. He went there with his family and started the work to expand and grow the church. Later a plot of land was bought where Flodine built the church. ${ }^{57}$

\section{Machakos church and the work in Ukambani}

The first SFM church in Ukambani was Makindu which was opened in 1965. ${ }^{58}$ This was following pioneering work of a man by the name Samuel who was sent by Struble. Sundin went to work in Machakos in 1968. A year later missionary Westina went and built a church in Kithaayoni, Machakos. In 1970, missionary Hellen brought a Tanzanian pastor from Chagaland and another lady called Elizabeth. They built

55 Rev. Daniel Kisemei, interview by Stephen Muoki Joshua, digital recording at FPFK headquarters on $29 \& 30$ October 2014.

56 Rev. Peter Odak, interview by Stephen Muoki Joshua, digital recording at FPFK headquarters on 29 October 2014.

57 Anania Mwangi, interview by David Musumba, digital recording at FPFK headquarters on 29 October 2014.

58 Pastor James Musau, interview by Stephen Muoki Joshua, digital recording at FPFK headquarters on $29 \& 30$ October 2014. 
a seven story house in Kithaayoni. Other churches opened were Tunguni (1977), Nzaikuni and Mithanga (1978). ${ }^{59}$

\section{CONCLUSION}

In this article, we have attempted to establish the historic relations between two foreign missionary agencies from Scandinavia and their new-found local church denomination following a merger in 1977. Further, the article has detailed key establishments of the SFM in Kenya in terms of church congregations as well as projects such as schools and bookshops. More importantly, however, the article dealt with the complex interplay between foreign Swedish missionaries' interests and the efforts of local African evangelists in the context of colonialisation and nationalisation in East Africa. Often, conflicts arose between African evangelists and missionary personnel resulting in the intervention of agency offices back in Sweden. Indeed, controversies and debates raged on in the mission field as well as in personal differences. Yet these could not match the zeal of the missionaries and the local ministers in sharing their faith with Kenyan peoples. As a result, the Gospel 'seeds' planted by Swedish missionaries since 1960 eventually grew into the big tree, the FPFK.

\section{REFERENCES}

Ayieye, J. and Gjervoldstad, V. 1999. Church Leaders Seminar: Leadership FPFK Structure Management, FPFK Capacity Building Programme, OD \&CB project manual, Nairobi, 4.

FPFK.1984 Annual General Meeting Minutes of FPFK, 2-15.

FPFK Organizational Documentation. 2001. The Constitution and Rules doc. 001. Nairobi: Uzima Centre.

Joshua, S.M. 2006. The interface between 'Missionary' and 'National' theological education in the Free Pentecostal Fellowship in Kenya: A historical perspective, Studia Historiae Ecclesiasticae, December 2006 XXXII(3): 173-191.

59 Pastor James Musau, interview by Stephen Muoki Joshua, digital recording at FPFK headquarters on $29 \& 30$ October 2014. 